\title{
Hubungan antara motivasi berprestasi dan pengetahuan pembuatan tes dengan kualitas soal buatan guru SMA dalam mata pelajaran bahasa Indonesia dan sastra di Kota Pangkalpinang
}

\author{
Asyraf Suryadin', Maulina Hendrik², \& Yorenza Meifinda3 \\ 1,2,3Universitas Muhammadiyah Bangka Belitung \\ ${ }^{1}$ Correspondence: Yorenza.y@gmail.com
}

\begin{abstract}
This study aims to determine, 1) the relationship between achievement motivation and the quality of questions made by high school teachers in Indonesian Language and Literature subjects, 2) the relationship between the knowledge of test making and the quality of questions made by high school teachers in Indonesian Language and Literature subjects. 3) the correlation between motivation of achievement and knowledge to make a test with the quality of SMA teacher's in subject of Indonesian language. The study was conducted by survey method correlational techniques. The target population is 30 high school teachers. The research concludes: first, there is a positive relationship between achievement motivation (X1) and the quality of teacher-made questions (Y), with a regression equation $\mathrm{Y}=$ $-12.50+0.69 \mathrm{X} 1$ and the correlation coefficient ry $1=0.37$ and the coefficient of determination $\mathrm{r} 2 \mathrm{y} 1=0,133$, secondly, there is a positive relationship between the knowledge of test making (X2) and the quality of questions made by high school teachers in Indonesian Language (Y) with regression $\mathrm{Y}=25,82+1,22 \mathrm{X}_{2}$ and correlation coefficient $\mathrm{r}^{2} \mathrm{y}=0$, 338, third the positive correlation between motivation of achievement ( X1) and knowledge to make a test (X2) with quality SMA teacher's in subject lesson of Indonesia language $(\mathrm{Y})$ with regression $\mathrm{Y}=-22,72+0,51 \mathrm{X} 1+1,12 \mathrm{X} 2$ and correlation coefficient $R_{\mathrm{y} .12}=0,64$, and determination coefficient $\mathrm{R}^{2} \mathrm{y}_{1.2}=$ 0,407 . This research hoped make the quality of SMA teacher's in subject lesson of Indonesia, such as to increase motivation of achievement and knowledge to make a test as well.
\end{abstract}

Keywords: Achievement motivation, test manufacturing knowledge, question quality 


\begin{abstract}
Abstrak
Penelitian ini bertujuan untuk mengetahui, 1) hubungan antara motivasi berprestasi dengan kualitas soal buatan guru SMA dalam mata pelajaran Bahasa Indonesia, 2) hubungan antara pengetahuan pembuatan tes dengan kualitas soal buatan guru SMA dalam mata pelajaran Bahasa Indonesia, 3) ada hubungan positif antara motivasi berprestasi dan pengetahuan pembuatan tes dengan kualitas soal buatan guru. Penelitian dilakukan dengan metode survei teknik korelasional. Dengan Sampel 30 guru, Hasil penelitian menyimpulkan: pertama, terdapat hubungan positif antara motivasi berprestasi $\left(\mathrm{X}_{1}\right)$ dengan kualitas soal buatan guru ( $\mathrm{Y})$, dengan persamaan regresi $\mathrm{Y}=-12,50+0,69 \mathrm{X}_{1}$ dan koefisien korelasi $\mathrm{r}_{\mathrm{y} 1}=0,37$ serta koefisien determinasi $\mathrm{r}_{\mathrm{y} 1}=0$, 133, kedua terdapat hubungan positif antara pengetahuan pembuatan tes $\left(\mathrm{X}_{2}\right)$ dengan kualitas soal buatan guru SMA ( $\mathrm{Y}$ ) dengan persamaan regresi $\mathrm{Y}=25,82+1,22 \mathrm{X}_{2}$ dan korelasi $\mathrm{r}_{\mathrm{y} 2}=0,58$ dan koefisien determinasi $\mathrm{r}^{2}{ }_{\mathrm{y} 2}=0,338$, ketiga terdapat hubungan positif antara motivasi berprestasi ( X1) dan pengetahuan pembuatan tes (X2) dengan kualitas soal buatan guru SMA ( $\mathrm{Y})$ dengan persamaan regresi $\mathrm{Y}=-22,72+0,51 \mathrm{X} 1+1,12 \mathrm{X} 2$ dan koefisien korelasi jamak $\mathrm{R}_{\mathrm{y} .12}=0,64$ dan koefisien determinasi $\mathrm{R}^{2} \mathrm{y} .2=0,407$. Hasil penelitian ini diharapkan dapat memperbaiki kualitas soal buatan guru, antara lain melalui peningkatan motivasi berprestasi serta penguasaan terhadap pembuatan tes dengan baik $\mathrm{r}_{\mathrm{y} 2}=0,58$
\end{abstract}

Kata kunci: Motivasi berprestasi, pengetahuan pembuatasn tes, kualitas soal

\title{
Pendahuluan
}

Evaluasi pendidikan mempunyai peranan penting dalam. Proses pendidikan secara keseluruhan, sebab untuk menentukan tujuan pendidikan, diperlukan hasil evaluasi yang telah dilakukan sebelumnya, seperti halnya dengan pengalaman pembelajaran. Pembelajaran yang dilakukan guru perlu di evaluasi untuk mengetahui seberapa tinggi pencapaian siswa akan pembelajaran tersebut. Karena pentingnya makna evaluasi bagi proses pendidikan, maka sudah selayaknya para guru untuk membuat soal -soal yang dapat digunakan sebagai alat ukur, sesuai dengan Peraturan Menteri Pendidikan dan Kebudayaan Nomor 4 tahun 2018 tentang penilaian hasil belajar oleh satuan Pendidikan dan penilaian hasil belajar oleh pemerintah.

Evaluasi berfungsi sebagai alat untuk mengetahui keberhasilan proses dan hasil belajar siswa. Proses adalah kegiatan yang dilakukan oleh siswa dalam mencapai tujuan pembelajaran, sedangkan hasil belajar adalah sejumlah 
pengetahuan dan keterampilan yang dimiliki siswa setelah mereka menerima pengalaman belajarnya (Supriyadi, 2013, hlm. ii).

Alat ukur yang berupa soal-soal dan diberikan kepada siswa tersebut hendaknya memenuhi kualitas yang baik.khusus dalam bidang evaluasi Bloom c.s. menyatakan pendapatnya bahwa evaluasi merupakan suatu proses pengumpulan dan analisa data secara sistematis untuk mengetahui bukti penguasaan peserta didik dalam belajar ketercapaian tujuan yang telah ditetapkan dan menentukan keefektifan pendidikan. Atau bisa disebut juga batasan ynag telah dikemukakan di dalam evaluasi ikut masuk juga dalam proses pengumpulan bukti untuk menentukan proses penguasaan peserta didik dalam belajar (Yusuf, 2017, hlm. 19).

Dalam penyelenggaran pembelajaran Bahasa Indonesia, sebagaiman halnya dalam penyelenggaraan pembelajaran bidang-bidang lain, evaluasi merupakan bagian yang tak terpisahkan dari penyelenggaraan pembelajaran secara keseluruhan. Sebagai suatu pembelajaran, pembelajaran Bahasa Indonesia diselenggarakan untuk mencapai sejumlah tujuan pembelajaran yang telah diidentifikasikan dan dirumuskan berdasarkan telaah mendalam terhadap kebutuhan yang perlu dipenuhi (Supriyadi, 2013, hlm. ii). Mata pelajaran Bahasa dan Sastra Indonesia memiliki empat aspek keterampilan yaitu, menyimak, berbicara, membaca, dan menulis. Menurut Waty soal buatan guru biasanya dilaksanakan diperiksa dinilai dan ditafsirkan hasilnya oleh guru yang bersangkutan, hal ini mengakibatkan soal buatan guru pada umumnya perlu distandarisasikan. Oleh sebab itu soal standar buatan guru perlu di standarisasi. Standarisasi tersebut dilakukan agar kualitas soal lebih memiliki validitas dan reliabilitas yang tinggi. Hal ini dilakukan untuk mengatasi seperti yang diungkapkan Masidjo bahwa, tes hasil belajar yang digunakan biasanya belum dicobakan pada kelompok besar siswa, sehingga pada umumnya, taraf reliabilitas, taraf validitas, taraf kesukaran,dan taraf pembeda item-itemnya belum menyakinkan ( Waty, 2017, hlm. 11).

Oleh sebab itu, banyak evaluasi dalam bidang pendidikan, terutama yang telah dipersiapkan oleh guru dibuaat tanpa pemikiran yang mendalam dan perencanaan yang teliti. Pada umumnya guru menyusun soal itu tanpa menghiraukan keseimbangan soal-soal, masalah ketepatan isi, dan masalah bentuk soal - soal kecuali secara kebetulan. Keseimbangan soal yang dimaksud pada pernyataan diatas meliputi, komposisi materi pelajaran berdasarkan tingkatan kelas di SMA.

Apabila ini terabaikan, maka evaluasi akan menjadi rendah keterpercayaannya. Selanjutnya, penyusunan soal-soal evaluasi biasanya langsung dihubungkan guru dengan tujuan pembelajaran yang tercantum dalam 
kurikulum 2013. Evaluasi yang dimaksud biasanya untuk mengukur tingkat keberhasilan siswa dan pada umunya dilakukan guru mata pelajaran yang bersangkutan. Hal ini wajar, dalam keadaan seperti itu, gurulah yang paling tahu apa yang dipelajari siswa dikelasnya sehingga dimungkinkan untuk membuat alat ukur tingkat keberhasilan secara tepat.

Penyusunan butir- butir soal tes prestasi belajar harus berlandaskan pada tujuan khusus dan deskripsi bahan yang telah diajarkan.dalam hal ini mungkin sekali terdapat perbedaan antara guru yang satu dengan yang lain walaupun sebidang mata pelajaran, seorang guru mungkin mengajar dengan cukup mendetail dalam cakupan yang luas. Sedangkan guru yang lain mungkin sebaliknya. Oleh karena itu, alat evaluasi yang disusun oleh guru hanya tepat diterapkan pada siswa yang diajarkan oleh guru yang bersangkuta dan tidak pada siswa yang lain apabila sekolah yang berbeda.maka untuk memperoleh soal yang baik, Arikunto menganjurkan soal buatan guru hendaknya disertai; kisi- kisi (blue print) untuk menyusun tes, bentuk soal, cara memberikan skor, cara mengolah dan apabila suda ada, perlu juga diinformasikan mengenai tingkat validitas dan reabilitasnya (Arikunto, 2010, hlm. 41).

Hal tersebut kurang diperhatikan, maka soal buatan guru hanya mempunyai daya jangkau pakai yang terbatas. Hasil atau skor yang dicapai siswa juga terbatas, dalam arti hanya diperbandingkan dengan teman- teman sekelompoknya yang satu sekolah. Perbandingan antara siswa dari satu sekolah dengan sekolah yang lain kurang tepat karena mugkin sekali alat ukur dan cara penafsiran yang dilakukan guru yang mengetes tidak sama. Jadi, apa yang disusun guru pada waktu itu, kemudian yang dievaluasikan bahkan mungkin untuk berkali-kali.

Kegiatan analisis dan revisi butir-butir soal jarang dilakukan. Itulah sebabnya materi, kontruksi soal bahasa, validitas, reliabilitas dan analisis butir soal yang terdiri dari tingkat kesukaran, daya pembeda dan pengecoh soal buatan guru sering dikatakan rendah, atau sebenarnya yang tepat adalah tidak diketahui secara pasti karena memang jarang dilakukan pengujian terhadap alat evaluasi seperti diatas dilakukan oleh guru atau sekelompok guru yang tergabung dalam MGMP. Usaha untuk mengatasi kelemahan tersebut seperti yang diutarakan diatas sebenarnya mudah jika guru mau mempelajari dan menerapkan teknik penyusunan dan pengolahan hasil penilaian yang tepat. Untuk soal buatan guru, yang paling diutamakan adanya kesesuaian antara tujuan, deskripsi bahan dan alat penilaian (Nurgiyantoro, 2018, hlm. 5).

Selain dari pada itu, adanya usaha pembuatan soal-soal yang disentralisasikan melalui musyawarah guru mata pelajaran, khususnya mata pelajaran yang di Ujiankan. Sementara kisi-kisinya, khusus untuk evaluasi sumatif bisanya sudah disiapkan oleh kantor Departemen Pendidikan Nasional 
Provinsi Bangka Belitung. Jadi, guru hanya membuat soal - soal berdasarkan kisi-kisi tersebut. Soal buatan yang terdiri dari beberapa guru mata pelajaran yang sama tersebut setidaknya hanya memenuhi kriteri materi, konstruksi soal, dan bahasa secara umum. Sedangkan untuk validitas, reliabilitas dan analisis butir soal tidak diketahui karena tidak pernah di ujicobakan. Tidak di ujicobakan tersebut karena rendahnya pengetahuan guru terhadap pembuatan tes presasi belajar (Nurgiyantoro, 2009, hlm.5).

Selain itu, motivasi berprestasi guru terhadap mata pelajaran yang menjadi binaanya pun harus tinggi agar diperoleh soal yang berkualitas baik. Dengan demikian sudah selayaknya guru memiliki motivasi berprestasi dalam penulisan soal dan pengetahuan pembuatan tes. Sebab hubungan antara kedua permasalahan yang telah diutarakan sangat erat dengan membuat soal berkualitas. Selain itu, untuk mengurangi kesenjangan antara harapan dan kenyataan yang terjadi dilingkungan dunia pendidikan dalam hal pembuatan soal. Apalagi soal buatan guru terutama dimaksudkan untuk mengetahui kadar pencapaian tujuan, tingkat penguasaan bahan oleh siswa, dan untuk memberikan nilai kepada siswa sebagai laporan hasil belajar di sekolah tersebut.seharusnya Program pendidikan guru membantu guru untuk mendapatkan pengetahuan dan keterampilan, mengembangkan sikap profesional, dan dampak keyakinan mereka tentang pembelajaran yang baik yang dapat mempengaruhi hasil belajar (Bahous \& Nabhani, 2011, hlm. 22).

Mengenai hubungan antara evaluasi dengan pengajaran bahwa pengukuran langkah awal pengajaran. Tanpa pengukuran tidak akan terjadi penilaian, tanpa penilaian tidak akan terjadi umpan balik, tanpa umpan balik tidak akan diperoleh pengetahuan yang baik tentang hasil, tanpa pengetahuan tentang hasil tidak dapat terjadi perbaikan yang sistematis dalam belajar. Melalui evaluasi seorang pengajar dapat: a) mengetahui apakah pembelajar mampu menguasai materi yang telah diajarkan, b) apakah mereka bersikap sebagaimana diharapkan, c) apakah mereka telah memiliki keterampilan berbahasa, d) mengetahui keberhasilan proses belajar mengajar yang telah dilaksanakan dan, e) menentukan kebijakan selanjutnya. (Supriyadi, 2013, hlm. 6).

Perwujudan unjuk kerja profesional guru ditunjang dengan jiwa profesionalisme, yaitu sikap mental yang senantiasa mendorong untuk mewujudkan diri sebagai guru profesional. Kualitas profesionalisme ditunjukkan oleh lima unjuk kerja, antara lain keinginan untuk senantiasa mengejar kesempatan pengembangan profesional yang dapat meningkatkan dan memperbaiki kualitas pengetahuan dan keterampilan, serta melaksanakan pekerjaan dengan mengedepankan kualitas dan cita- cita dalam profesi (Aqib \& Rohmanto, 2008, hlm. 145-146). 
Dalam melaksanakan evaluasi dan penilaian, guru dituntut untuk dapat membuat soal tes yang berkualitas baik dan hasil tes tersebut benar-benar dapat memberikan informasi yang tepat tentang siswa mana yang telah/belum menguasai materi yang telah diajarkan. Dalam beberapa kasus ditemui beberapa kekurangan guru dalam menyusun dan melaksanakan evaluasi belajar diantaranya; a) adanya kecendrungan untuk bersifat subjektif terhadap hasil penilaian yang dilakukan guru terhadap siswa. b) soal-soal yang dibuat kurang berorientasi pada evaluasi terpadu khususnya untuk mata pelajaran Bahasa dan Sastra Indonesia. c) guru lebih suka menggunakan soal yang telah tersedia, misalnya dari kumpulan soal yang dibuat oleh berbagai penerbit.

Rumusan masalah dalam penelitian ini yaitu :a)apakah ada hubungan antara motivasi berprestasi dengan kualitas soal buatan guru SMA dalam mata pelajaran Bahasa Indonesia, b) apakah ada hubungan antara pengetahuan pembuatan tes dengan kualitas soal buatan guru SMA dalam mata pelajaran Bahasa Indonesia. c) apakah ada hubungan antara motivasi berprestasi dan pengetahuan pembuatan tes dengan kualitas soal buatan guru SMA dalam mata pelajaran Bahasa Indonesia. Tujuan dari penelitian ini untuk melihat hubungan antara motivasi berprestasi dengan kualitas soal buatan guru SMA dalam mata pelajaran Bahasa dan Sastra Indonesia, dan melihat hubungan antara pengetahuan pembuatan tes dengan kualitas soal buatan guru SMA dalam mata pelajaran Bahasa dan Sastra Indonesia.

Manfaat dari penelitian ini adalah sebagai masukan bagi guru SMA di Pangkalpinang dalam rangka penyempurnaan soal berdasarkan temuan hasil penelitian dan sebagai langkah awal pengembangan soal Bahasa Indonesia dari sekumpulan butir-butir soal yang baik berdasarkan hasil penelitian, sebagai bahan masukan sekolah untuk menentukan pen-dampingan atau pelatihan lebih lanjut kepada guru terkait perencanaan, penyusunan, dan pengelolaan soal Bahasa Indonesia yang dibuat oleh guru.

\section{Metode}

Penelitian ini menggunakan metode survei dengan teknik analisis korelasi. Metode survei memberikan gambaran tentang variabel-variabel yang ditemukan, dan menyelidiki hubungan antarvariabel.metode ini dapat memberikan informasi tentang variabel secra faktual berdasarkan kenyataan lapangan (Sugiyono, 2013, hlm. 13).

Teknik korelasi digunakan untuk mengetahui: a) hubungan antara pasangan skor variabel motivasi berprestasi $\left(\mathrm{X}_{1}\right)$ dengan skor kualitas soal buatan guru SMA dalam mata pelajaran Bahasa Indonesia (Y). b) mengetahui hubungan antara pasangan skor variabel pengetahuan pembuatan tes $\left(\mathrm{X}_{2}\right)$ dengan skor 
kualitas soal buatan guru SMA dalam mata pelajaran Bahasa dan Sastra Indonesia.

Populasi dalam penelitian ini adalah guru SMA yang mengajar mata pelajaran Bahasa Indonesia di Kota Pangkalpinang sebanyak 30 guru. Ada tiga instrumen yang digunakan pada penelitian ini, yaitu: a) instrumen berupa skala sikap yang bertujuan untuk mengetahui motivasi berprestasi yang berkaitan dengan evaluasi hasil belajar. b) Instrumen kedua berupa tes kemampuan pengetahuan pembuatan tes $\left(\mathrm{X}_{2}\right)$. c) kualitas soal buatan guru tidak menggunakan instrumen yang dibuat peneliti namun dibuat oleh guru berupa soal-soal mata pelajaran Bahasa Indonesia, peneliti hanya membuat kriteria atau norma untuk mengetahui kualitas soal buatan guru.

Penelitian ini menggunakan teknik pengumpulan data non tes, tes dan dokumentasi. Teknik non tes digunakan untuk menjaring data motivasi berprestasi $\left(\mathrm{X}_{1}\right)$ sedangkan teknik tes digunakan untuk menjaring data penguasaan teknik evaluasi pendidikan $\left(\mathrm{X}_{2}\right)$. Untuk data kualitas soal buatan guru SMA (Y) menggunakan teknik dokumentasi. Data kemudian dianalisis dengan menggunakan bantuan program anates versi 4, yang meliputi validitas, reabilitas, tingkat kesukaran, daya pembeda dan pengecoh. Untuk data daya pembeda, tingkat kesukaran dan serta efektivitas pengecohdiperoleh dengan analisis statistic. Pada tahap teknik analisis data ada dua teknik yang digunakan yaitu teknik analisis data ujicoba instrumen dan teknik analisis data hasil penelitian.Instrumen kesatu yang tidak valid sebanyak 9 butir dan instrumen kedua yang tidak valid sebanyak 11 butir.Ada tiga hal yang dikaji dalam upaya ujicoba instrumen kedua pada analisis butir soal yaitu, tingkat kesukaran butir soal, daya beda butir soal, dan pengecoh. Berdasarkan tabel dibawah ujicoba instumen terhadap perangkat soal dan hasil analisisnya diperoleh data memenuhi kriteria baik, sedangkan pada tataran pengecoh lebih banyak dipilih pada kelompok bawah atau rendah.

Tabel 1. Hasil rangkuman analisis ujicoba instrumen

\begin{tabular}{llll}
\hline No & Jenis analisis & \multicolumn{1}{c}{ Nilai instrumen } & \multicolumn{1}{c}{ Nilai instrumen } \\
\hline & & $0,36-0,69$ & Kedua \\
\hline 1 & validitas & 0,84 & $0,36-0,74$ \\
\hline 2 & reliabilitas & 0,94 \\
\hline 3 & Tingkat kesukaran & - & $0,47-0,83$ \\
\hline
\end{tabular}




\begin{tabular}{llll}
\hline 4 & Daya beda & - & 0,27-0,80 \\
\hline 5 & Pengecoh & - & dipilih kelompok bawah \\
\hline
\end{tabular}

Teknik analisis data penelitian, data penelitian harus memenuhi persyaratan yaitu normalitas data dengan cara diuji terlebih dahulu (Sudjana, 2017, hlm. 50). Pengujian normalitas data dilakukan dengan menggunakan uji Lilliefors karena data tidak merupakan data kelompok melainkan data tunggal (Sudjana, 2015, hlm. 466). Kemudian untuk analisis data penelitian hipotesis kesatu dan kedua menggunakan rumus korelasi sederhana dan hipotesis ketiga menggunakan rumus korelasi multiple. Seperti telah dikemukakan sebelumnya, pada penelitian ini digunakan dua variable bebas yaitu, motivasi berprestasi ( X1) dan pengethuan pembuatan tes ( X2) dengan variabel terikat kualitas soal buatan guru SMA dalam mata pelajaran Bahasa Indonesia ( Y).

\section{Hasil dan pembahasan}

Menurut Sudijono Evaluasi Pendidikan mempunyai peranan penting dalam Pendidikan, evaluasi dapat mendorong sisa untuk lebih giat belajar secara terus menerus dan juga mendorong guru untuk lebih meningkatkan kualitas proses pembelajaran serta mendorong sekolah untuk lebih meningkatkan fasilitas dan kualitas manajemen sekolah. Sehubungan dengan hal tersebut, maka didalam pembelajaran dibutuhkan guru yang tidak hanya mampu mengajar dengan baik tetapi juga mampu melakukan evaluasi dengan baik. Kegiatan evaluasi sebagai bagian dari program pembelajaran perlu di optimalkan. Evaluasi tidak hanya bertumpu pada penilaian hasil belajar, tetapi juga perlu penilaian terhadap input, output maupun kualitas proses pembelajaran itu sendiri.

Berdasarkan data yang telah dikumpulkan, rentang otentik dari hasil motivasi berprestasi guru adalah 21 sampai 105. Rentang tersebut diperoleh dari 21 butir soal dengan skor terendah 83 dan skor tertinggi 99, sedangkan skor ratarata sebesar 91,30, simpangan baku sebesar 4,23 dan varians sebesar 17,94. Sementara itu, modus sebesar 89,67 dan 95,01 disebut juga modus bimodel serta media 90,67 dengan jumlah data (n) sebesar 30. Untuk distribusi frekuensi sebagaimana tampak pada tabel berikut:

Tabel 2. Distribusi frekuensi hasil motivasi berprestasi

\begin{tabular}{clll}
\hline \multicolumn{1}{c}{ Nilai } & Tanda kelas & $\mathrm{f}_{\mathrm{a}}$ & \multicolumn{1}{c}{$\mathrm{F}_{\mathrm{r}}(\%)$} \\
\hline $83,00-85,66$ & 84,33 & 3 & 10,00 \\
\hline $85,67-88,33$ & 87,00 & 5 & 16,67 \\
\hline $88,34-91,00$ & 89,67 & 8 & 26,67 \\
\hline
\end{tabular}


Hubungan antara motivasi berprestasi dan pengetahuan pembuatan tes dengan kualitas soal buatan guru SMA dalam mata pelajaran bahasa Indonesia dan sastra di Kota Pangkalpinang

\begin{tabular}{clll}
\hline $91,01-93,67$ & 92,34 & 3 & 10,00 \\
\hline $93,68-96,34$ & 95,01 & 8 & 26,67 \\
\hline $96,35-99,01$ & 97,68 & 3 & 10,00 \\
\hline$£$ & & 30 & $100 \%$ \\
\hline
\end{tabular}

Berdasarkan tabel diatas terdapat 53,34\% atau 16 responden memiliki skor motivasi berprestasi dibawah skor rata-rata. Kemudian hanya 10\% atau 3 responden pada skor rata-rata dan 36,67\% atau sebanyak 11 responden diatas skor rata-rata. Kemudia berdasarkan grafik dapat digambarkan sebagai berikut.

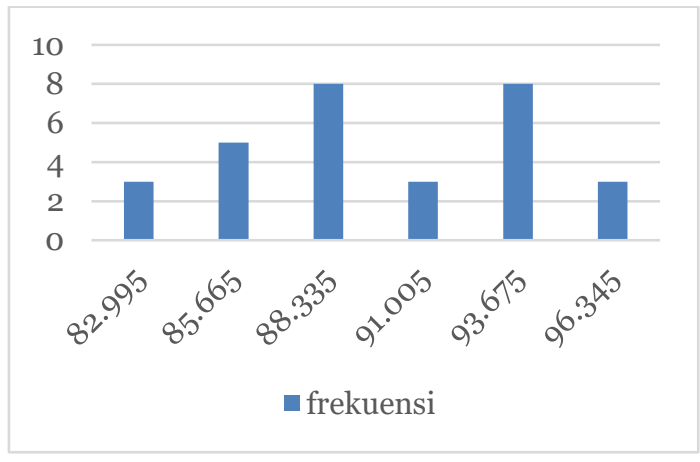

\section{Gambar 1. Hasil motivasi belajar}

Berdasarkan data yang dikumpulkan, rentang otentik dari hasil pengetahuan pembuatan tes adalah 1 sampai dengan 29. Rentang tersebut diperoleh dari jumlah penilaian yang betul dari 29 butir soal yang dijawab oleh responden. Selanjutnya, diperoleh rentang skor sebesar 17, skor terendah 10, dan skor tertinggi 27. Sedangkan skor rata-rata sebesar 20,23. Simpangan baku 3,81 dan varians sebesar 14,51. Sementara itu, modus sebesar 19,91 dan untuk median sebesar 5,81 dengan jumlah data ( $n$ ) sebesar $30^{2}$. Kemudia distribusi frekuensi sebagaimana tampak pada tabel dibawah ini:

Tabel 3. Distribusi frekuensi hasil pengetahuan pembuatan tes

\begin{tabular}{clll}
\hline & \multicolumn{1}{c}{$\begin{array}{c}\text { Tanda } \\
\text { kelas }\end{array}$} & \multicolumn{1}{c}{$\mathrm{f}_{\mathrm{a}}$} & \multicolumn{1}{c}{$\mathrm{F}_{\mathrm{r}}(\%)$} \\
\hline $10,00-12,83$ & 11,42 & 1 & 3,33 \\
\hline $12,84-15,67$ & 14,26 & 3 & 10,00 \\
\hline $15,68-18,51$ & 17,09 & 5 & 16,67 \\
\hline $18,52-21,35$ & 19,94 & 11 & 36,67 \\
\hline $93,68-96,34$ & 22,78 & 4 & 13,33 \\
\hline $96,35-99,01$ & 25,62 & 6 & 20,00 \\
\hline$£$ & & 30 & $100 \%$ \\
\hline
\end{tabular}


Tabel 3 di atas memberikan isyarat bahwa ada 30\% atau 9 responden yang memiliki penguasaan teknik evaluasi pendidikan dibawah skor rata-rata. Kemudian sebanyak 36,67\% atau 11 responden pada skor rata-rata dan 33, 33\% atau sebanyak 10 responden diatas rata-rata. Selanjutnya, berdasarkan tabel distribusi diatas, grafiknya dapat digambarkan sebagai berikut:

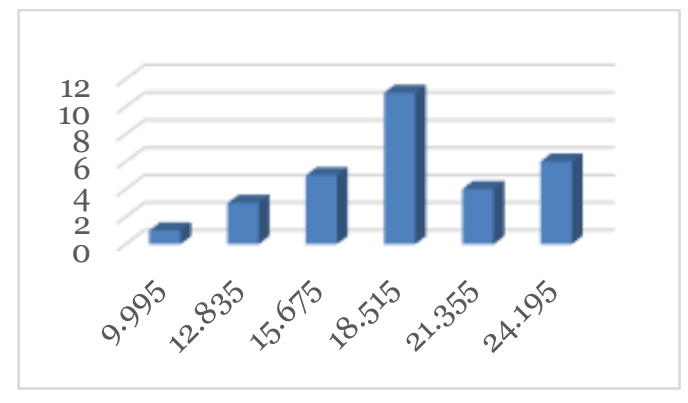

\section{Gambar 2. Hasil pengetahuan pembuatan tes}

Untuk data hasil kualitas soal buatan guru SMA dalam mata pelajaran Bahasa Indonesia diperoleh rentang skor teoritik sebesar untuk validitas butir soal buatan guru sebesar 35 sampai dengan 140. Skor tersebut diperoleh dari masing-masing 35 butir soal dengan skor 1-4. Sedangkan rentang skor teoritik untuk reliabilitas dikonversikan dengan T-skor. Hasil konversi diperoleh rentang skor sebesar 31, 61 skor terendah 33,77 dan skor tertinggi 65,38. Sedangkan skor rata-rata sebesar 50,50. Simpangan baku 8,03, dan varians sebesar 64,46. Sementara itu modus sebesar 52,21 dan untuk media sebesar 1,33 dengan jumlah data sebanyak 30. Distribusi frekuensi sebagaimana tampak pada tabel berikut:

Tabel 4. Distribusi frekuensi hasil kualitas soal buatan guru SMA dalam mata pelajaran Bahasa Indonesia

\begin{tabular}{llll}
\hline \multicolumn{1}{c}{ Nilai } & Tanda kelas & $\mathrm{f}_{\mathrm{a}}$ & \multicolumn{1}{c}{$\mathrm{F}_{\mathrm{r}}(\%)$} \\
\hline $33,77-39,03$ & 36,40 & 3 & 10,00 \\
\hline $39,04-44,30$ & 41,67 & 5 & 16,67 \\
\hline $44,31-49,57$ & 46,94 & 4 & 13.33 \\
\hline $49,58-54,84$ & 52,21 & 9 & 30,00 \\
\hline $54,85,-60,11$ & 57,48 & 7 & 23,33 \\
\hline $60,12-65,38$ & 62,75 & 2 & 6,67 \\
\hline$£$ & & 30 & $100 \%$ \\
\hline
\end{tabular}

Tabel 4 di atas memberikan gambaran dari 30 responden yang memiliki hasil pengetahuan pembuatan tes Kemudian Relatif variabel bebas $\left(\mathrm{X}_{1}\right)$ terhadap variabel terikat ( $\mathrm{Y}$ ) selain itu, keofisien korelasinya $\mathrm{r}_{\mathrm{y} 1}$ sebesar 0,3 . 
Berdasarkan hasil penelitian hubungan antara motivasi berprestasi dengan kualitas soal buatan guru SMA dalam mata pelajaran Bahasa Indonesia, hipotesi pertama menunjukkan bahwa terdapat hubungan positif variable bebas ( X1) dengan variable terikat ( Y). Pernyataan ini didsarkan pada hasil koefisien korelasi sebesar $r_{y 1}=0,37$ dan uji signifikansi korelasi yang diperoleh sebesar thitung $=3,06$. Jauh dari nilai ttabel yang hanya sebesar 1,70 pada taraf signifikansi $\propto=0,05$. Kemudia besarnya sumbangan relative motivasi berprestasi terhadap kualitas soal buatan guru seperti terwujud pada $\mathrm{r}^{2}$ y1 sebesar $13,30 \%$ persentase tersebut memberika arti bahwa motivasi berprestasi sangat menopang terhadap kualitas soal buatan guru dalam mata pelajaran Bahasa dan Sastra Indonesia, walaupun sumbangan relative tersebut sangat kecil.

Hubungan antara pengetahuan pembuatan tes dengan kualitas soal buatan guru SMA dalam mata pelajaran Bahasa Indonesia, pengujian hipotesis kedua menunjukkan bahwa terdapat hubungan antara pengetahuan pembuatan tes dengan kualitas soal buatan guru SMAA mata pelajaran Bahasa Indonesia, dikatakan demikian karena hubungan diantara variable bebas ( X2) dengan variable terikat ( $\mathrm{Y}$ ) memiliki koefisien korelasi $\mathrm{r}_{\mathrm{y} 2}$ sebesar 0,58 . Sedangkan pada hasil uji signifikansi korelasi diperoleh thitung sebesar 3,78 sangat jauh dari nilai tabel yang hanya sebesar 1,70 pada taraf signifikansi $\propto=0,05$. Selain hubungan yang sangat positif diantara kedua variable tersebut. Variable bebas ( X2) memberikan sumbangan relative yang lebih besar dari variable bebas ( X1) yaitu33, 80\% terhadap kualitas soal buatan guru SMA dalam mata pelajaran Bahasa Indoenesia. Persentase sebesar 33,80\% diinterpretasikan bahwa guru lebih menguasai Teknik evaluasi Pendidikan dari pada motivasi berprestasi dalam melaksanakan tugas membuat soal.

Hubungan motivasi berprestasi dan pengetahuan pembuatan tes dengan kualitas soal buatan guru SMA dalam mata pelajaran Bahasa Indonesia, berdasarkan pengujian hipotesis ketiga, diperoleh adanya korelasi yang sangat signifikansi antara dua variable bebas ( $\mathrm{X} 1$ dan $\mathrm{X} 2$ ) terhadap variable terikat ( Y) sebesar Ry.12 $=0,64$ dan uji signifikansi diperoleh Fhitung $=9,25$ lebih besar dari $\mathrm{F}_{\text {tabel }}=3$ 3,35. Kesignifikansi tersebut memberikan interpretasi bahwa motivasi berprestasi sangat mempengaruhi dalam pembuatan soal. Demikian juga dengan pengetahuan pembuatan tes yang dimiliki guru mempunyai pengaruh terhadap kualitas soal buatan guru SMA dalam mata pelajaran Bahasa Indonesia. Oleh sebab itu, kedua variable yang saling keterhubungan tersebut sudah selayaknya untuk ditingkatkan baik yang berasal dari motivasi berprestasi guru dan pengetahuan pembuatan tes maka akan semakin meningkatkan kualitas soal buatan guru. 
Hasil penelitian mengisyaratkan bahwa sumbangan relative motivasi berprestasi lebih kecil apabila dibandingkan dengan penguasaan guru terhadap pengetahuan pembuatan tes. Indikator rendahnya motivasi berprestasi ini diperoleh dari hasil bobt sumbangan relative variable bebas ( X1) terhadap varaibel terikat ( $Y$ ). Selain itu, koefisien korelasinya $r_{\mathrm{y} 1}$ sebesar 0,37 . Rendahnya motivasi berprestasi dapat dimaklumi: pertama, sampel penelitian kebanyakan guru yang berstatus bukan Pegawai Negeri Sipil. Jumlah yang berstatus Pegawai Negeri Sipil sebanyak Sembilan orang, sedangkan 21 guru berstatus honorer. Kedua, guru SMA yang mengajar mat a pelajaran Bahasa Indonesia di Kota Pangkalpinang pengalaman mengajarnya masih minim. Hal ini terungkap saat peneliti mengadakan wawancara secara lisan yang rata-rata pengalaman mengajar dibawah 5 tahun. Kedua kendala tersebut menjadi factor motivasi berprestasi. Akibat daripada itu semua, soal-soal buatan guru tersebut kebnyakan dibuat tanpa memperhatikan kaidah-kaidah yang berlaku termasuk keinginan untuk membuat soal yang baik. Pernyatan ini diperkuat oleh Halim, bahwa evaluasi dalam bidang Pendidikan, terutama yang dipersiapkan oleh guru dibuat tanpa pemikiran yang mendalam dan perencanaan yang teliti. Pada umumnya mereka menyusun soal tanpa menghiraukan masalah keseimbangan soal-soal, masalah ketepatan isi, dan masalah bentuk soal-soal kecuali secara kebetulan. Apabila ini terjadi, maka evaluasi seperti ini di sangsikan ketepatannnya rendah sekali taraf kepercayaannya (Halim, 1974: 133). Walaupun demikian motivasi berprestasi pada penelitian ini cukup signifikan terhadap kualitas soal buatan guru SMA dalam mata pelajaran Bahasa Indonesia.

Kemudian sumbangan relative pada variable (X2) lebih baik dikuasai guru. Penguasaan terhadap pengetahuan pembuatan tes tersebut dapat dimaklumi karena pada saat melaksanakan Pendidikan di Universitas materi yang berhubungan dengan evaluasi Pendidikan secara teori pernah diterima oleh guru. Menurut Suryabrata penyajian soal secara secra teoritis ini disebut penelaah soal atau telaah soal. Untuk melakukan penelaah soal ini dilakukan tiga kemampuan (keahlian), yaitu: a) keahlian dalam bidang studi yang diuji, b) keahlian dalam pembahasan gagasan. Untuk dua keahlian yang pertama jelas ada program Pendidikan formal yang menyiapkan. Sedangkan untuk keahlian ketiga tidak, tetapi ahli Bahasa dapat memikul tugas ini, hanya saja kegiatan untuk menguji coba soal-soal buatan guru tersebut kepada siswa tidak pernah dilakukan. Bukan berarti kemampuan guru tersebut rendah, tetapi lebih dialasankan pada kesempatan untuk melaksanakan termasuk juga dengan kemampuan sekolah masing-masing.

Penjelasan diatas memberi masukan bahwa perlunya memupuk motivasi guru dan menambah pengetahuan pembuatan tes. Baik motivasi berprestasi maupun pengetahuan pembuatan tes merupakan usaha untuk melihat kualitas 
soal. Kemampuan guru menulis soal lebih merupakan kiat daripada ilmu, walupun tidak dapat dipungkiri pengetahuan tentang hal-hal teknis dalam penulisan soal akan meningkatkan kemampuan menulis soal. Kemampuan menulis soal menuntut kombinasi berbagai kemampuan khusus yang hanya dapat dikembangkan secara lambat laun melaui latihan dan pengalaman, dengan selalu mengingat rambu-rambu teknis tentang penulisan soal.

\section{Kesimpulan}

Kesimpulan yang dapat ditarik dari hasil penelitian diatas yaitu: a) terdapat hubungan antara motivasi berprestasi dengan kualitas soal buatan guru SMA dalam mata pelajaran Bahasa dan Sastra Indonesia, kesimpulan ini memberikan arti, bahwa semakin termotivasi untuk berprestasi, maka akan berkualitas pula soal buatan guru. Sebaliknya, makin kurang motivasi berprestasi seorang guru, maka kualitas soal buatan guru SMA dalam mata pelajaran Bahasa dan Sastra Indonesia akan kurang baik. b) terdapat hubungan antara pengetahuan pembutan tes dengan kualitas soal buatan guru SMA dalam mata pelajaran Bahasa Indonesia, kesimpulan ini mengungkapkan bahwa pada semakin baik pengetahuan pembuatan tes maka semakin berkualitas soal buatan guru SMA dalam mata pelajaran Bahasa dan Sastra Indonesia, demikian pula sebaliknya, semakin kurang baik pengetahuan pembuatan tes, maka semakin kurang berkualitas pula soal buatan guru tersebut. c) terdapat hubungan antara motivasi berprestasi dan pengetahuan pembuatan tes dengan kualitas soal buatan guru SMA dalam mata pelajaran Bahasa dan Sastra Indonesia. Kesimpulan ini memberikan arti bahwa semakin baik motivasi berprestasi dan pengetahuan pembuatan tes maka semakin berkualitas soal buatan guru dalam mata pelajaran Bahasa dan Sastra Indonesia yang dibuatnya.

Berdasarkan hasil penelitian dan kesimpulan maka ada beberapa hal yang perlu diperhatikan sebagai tindak lanjut atau implikasi, yaitu: a) mengembangkan motivasi berprestasi pendidik, dengan mengembangkan motivasi berprestasi peserta didik maka kualitas soal buatan guru akan semakin baik, b) karena berdasarkan kendala yang ditemukan lebih banyak berhubungan dengan aspek pengetahuan serta motivasi berprestasi pendidik maka implikasi prkatisnya adalah perlu ditingkatkan keterampilan dan keprofesionalan pendidik. c) penting untuk melakukan perbaikian dalam memilih jenis soal sesuai dengan kemampuan peserta didik serta indikator yang harus dicapai peserta didik d) terhadap pengambilan kebijakan, diharapkan kepada Kepala Kantor Departemen Pendidikan Nasional Kota Pangkapinang dan Kepala Sekolah, kiranya dapat dijadikan sebagai bahan pertimbangan dalam menyusun 
soal-soal yang dilakukan oleh guru. Apalagi soal- soal yang berhubungan dengan mata pelajaran yang di ujian sekolahkan.

\section{Daftar rujukan}

Arikunto, S. (2010). Dasar-dasar evaluasi pendidikan (Edisi Revisi). Pt.Bumi Aksara.

Aqib, Z., \& Elham, R. (2008). Membangun profesionalisme guru dan pengawas sekolah. Rama Widya.

Halim, A., Jazir, B., \& Al Rasjid, H.( 1974). Ujian bahasa. Ganaco.

Nurgiyantoro, B. (2009). Penilaian dalam pengajaran bahasa sastra. Gadjahmada University Press.

Nurgiyantoro, B. (2018). Penilaian otentik dalam pembelajaran bahasa. Gadjahmada University Press.

Sardiman. (2001). Interaksi dan motivasi belajar mengajar. Raja Grafinda Persada.

Sudijono, A. (2006). Pengantar evaluasi pendidikan. Rajawali Pers.

Sudjana. (2018). Desain dan analisis eksperimen. Tarsito.

Sudjana. (2005). Metode statistik. Tarsito.

Supriyadi. (2013). Evaluasi pembelajaran bahasa Indonesia. UNG Press Gorontalo.

Sugiyono, (2013), Metodologi penelitian kuantitatif, kualitatif dan pengembangan. Alfabeta.

Waty, E. (2017). Menelaah kualitas soal ujian sekolah buatan guru pada penacapaian kelulusan siswa. JPPM. 4(2): 18-22.

Yusuf, M. (2017). Assesment \& evaluasi pendidikan. Kencana.

Bahous, R., Bacha, N., \& Nabhani, M. (2011). Motivating in the EFL classroom: A case study of perspectives, English language teaching. Canadian Center Of Science \& Education, 4(3):33-43.

Yonelia, V., Haryati, S., \& Azmi, J. (2014). Analisis butir soal ujian semester genap mata pelajaran kimia kelas X IPA SMA PGRI Pekanbaru tahun ajaran 2013/2014. Jomfkip.

Kemendikbud. (2018). Permendikbud nomor 4 tahun 2018 tentang penilaian hasil belajar oleh satuan pendidikan dan penilaian hasil belajar oleh pemerintah. Kemendikbud. 